\title{
Ratlarda Siklofosfamid Nedenli Kardiyotoksisite Üzerine Borik Asitin Koruyucu Etkileri
}

\author{
Mustafa CENGIZ ${ }^{1 *}$
}

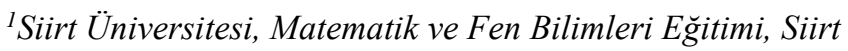

\begin{abstract}
$\ddot{O} \mathbf{z}$
Bir eser element olan Bor'un türevi olan Borik asit (BA), antioksidan özellikleri ve antioksidan savunma sistemi güçlendirici özellikleri ile bilinen bir bileşiktir. Bu deneysel çalışma, sıçanlarda BA'nın siklofosfamid (CP) nedenli akut kalp toksisitesi üzerindeki koruyucu etkilerini araştırmayı amaçlamaktadır. Bu amaçla erkek sıçanlar, her grupta 6 hayvan olacak şekilde 4 gruba ayrılmıştır (kontrol, CP $(200 \mathrm{mg} / \mathrm{kg}$ ) grubu, BA $(200 \mathrm{mg} / \mathrm{kg})$ grubu ve $\mathrm{BA}+\mathrm{CP}$ grubu). Deney sonunda histolojik ve biyokimyasal değerlendirmeler için ketamin/ksilazin anestezisi altında hayvanların doku ve kan örnekleri toplanmıştır. Tek doz SF verilen grupta, kreatin kinaz (CK-MB), laktat dehidrojenez (LDH) ve miyokardtaki hücresel boyuttaki değişimlerin bir işareti olarak kabul edilen iskemi modifiye albümin (IMA) gibi kardiyak biyokimyasal belirteçlerin anlamlı olarak arttı̆̆ görülmüştür. Diğer taraftan, BA ile ön koruma yapılan BA+CP grubunda CK-MB, LDH ve IMA düzeyleri anlamlı düzeyle azalmıştır. Bulgularımız, BA tedavisinin sıçanlar üzerindeki SF nedenli toksik etkileri başarılı bir şekilde azalttığını göstermiştir. Sonuçlarımız, BA ön tedavisinin kemoterapi protokollerinde ilaç nedenli toksisiteleri azaltmada yararlı olabileceği fikrini güçlendirmektedir.
\end{abstract}

Anahtar kelimeler: Siklofosfamid, Kardiyo Toksisitesi, Borik Asit, Kardiyoprotektif, IMA.

\section{The Prevention Effects Boric Acid on Cyclophosphamide induced Cardiotoxicity in Rats}

\begin{abstract}
Boric acid (BA), a derivative of the trace element boron, is a compound known for its antioxidant properties and antioxidant defense system constituent properties. The present study aims to investigate the protective effects of BA on acute cardiotoxicity of Cyclophosphamide (CP) in experimental rats. With these aims, rats were randomly divided into 4 groups of 6 animals in each (control, CP group, BA group and BA plus CP group). Tissue and blood samples of the animals were collected for morphological and biochemical evaluations. In group given $\mathrm{CP}$, cardiac biochemical markers such as creatine kinase (CK-MB), lactate dehydrogenase (LDH) and ischemia modified albumin (IMA), which is regarded as a sign of structural change, levels were significantly increased. On the other hand, CK-MB, LDH and IMA levels decreased in group given BA before CPadministration. Our results suggest that $\mathrm{B}$ treatment for the toxin administration successfully altered the toxic effects on the rats. In conclusion, BA treatment before $\mathrm{CP}$ intoxication might protect heart tissues against $\mathrm{CP}$-induced toxicity.
\end{abstract}

Keywords: Cyclophosphamide, Cardio Toxicity, Boric Acid, Cardioprotectivity, IMA.

\section{Giriş}

Siklofosfamid (CP), 50 yılı aşkın bir süredir geniş spektrumlu klinik kullanımları olan katı tümörler ve lenfomalar dahil neoplastik hastalıkların, romatoid artrit ve sistemik lupus eritematosus gibi neoplastik olmayan hastalıkların tedavisinde yaygın olarak kullanılan bir sitotoksik alkilleyici ajandır [1]. Ancak, kalp, testis ve idrar kesesi gibi organlarda toksisiteye sebebiyet vermesi, CP'nin klinik kullanımını kısıtlayan bir faktördür [2].

\footnotetext{
*Sorumlu yazar: m.cengiz@siirt.edu.tr 
Sitotoksik bir ilaç olan $\mathrm{CP}$, karaciğerde hidroksillenerek metabolitleri olan fosforamid mustard (phosphoramide mustard=PAM=FAM) ve akroleine (acrolein=ACR) dönüşmektedir. CP'nin antineoplastik etkileri PAM ile ilişkilidir. PAM'ın DNA'ya bağlanarak hücre bölünmesini baskılayıp CP'nin bağışıklık baskılayıcı ve antitümör etkilerine aracı olduğu düşünülmektedir. CP'nin toksik etkisinin ise aktif metaboliti olan ACR ile ilgili olduğu sanılmaktadır. ACR, doku antioksidan (AO) savunma sistemine müdahale ederek yüksek oranda serbest radikal oluşumuna yol açmaktadır [3]. Oksidatif stres, serbest oksijen radikali (SOR) miktarındaki artışla seyreden bir durumdur ve bu artış zarlarda lipit peroksidasyonuna neden olmaktadır [4]. SOR'ların inflamatuvar süreç içerisinde aşırı üretimi oksidatif strese neden olur ve bu da hücre ve DNA hasarlanması, protein denatürasyonu ve zar lipitlerinin peroksidasyonunu da içeren mekanizmalar yoluyla nekroza yol açmaktadır [2]. Memeli kalp dokusu hücrelerinde yapılan bir çalışmada CP terapisi boyunca SOR' un aşırı üretiminin lipid peroksidasyonu yaptığı ve oluşan membran hasarının miyokardiyal membranın bütünlügünü bozduğu ve fonksiyon bozukluğuna neden olduğu rapor edilmiş̧ir [5]. Shanholtz [6] yaptığı çalışmada, yüksek doz CP uygulamasının ölümcül kardiotoksisiteye neden olabileceğini vurgulamıştır. Başka bir çalışmada, CP'nin kardiyotoksik etkilerinin, doza bağlı kardiyak hasar, morfolojik olarak belirlenen nekroz, kanama ve akabinde gelişen fibrozis olduğu belirtilmiştir [7]. BA, kanser ve inflamatuar hastalık tedavilerinde yara iyileşmesi, oksidatif stresin önlenmesi, ağır metallerin toksik etkilerinin azaltılması ve düzenlenmesinde kullanılan antioksidan ve anti-inflamatuar özelliklere sahip bir eser element türevi olan bir bileşiktir. [8-10]. Bu çalışmada CP nedenli oksidatif stres ve kalp hasarı üzerine BA'nın olası kardiyoprotektif etkisi bir sıçan modelinde ilk kez test edilmiştir.

\section{Materyal ve Metot}

\subsection{Kimyasal maddeler ve gruplar}

\% 99 oranında saf BA ve CP $(25 \mathrm{mg} / 500 \mathrm{ml})$ ticari şirketten (Sigma-Aldrich, Darmstadt, Almanya) satın alınmıştır. BA ve CP i.p. olarak uygulanmıştır. Bu çalışmada 180-240 gr ağırlığında 24 adet Sprague Dawley erkek sıçan kullanılmıştır. Siçanlar, pelet ve musluk suyu ile beslendikleri kontrollü laboratuar koşullarında tutulmuştur. Deney hayvanları rastgele her biri 6 sıçan içeren 4 gruba ayrılmıştır. Otomatik kontrol edilen odalarda, $\% 45 \pm 50$ oranında nem, $22 \pm 2{ }^{\circ} \mathrm{C}$ sıcaklıkta, gün 1şı̆̆ında ve karanlıkta 12/12 saat tutulmuştur. $\mathrm{Bu}$ çalışmada izlenen tüm hayvan prosedürleri Eskişehir Osmangazi Üniversitesi Hayvan Refahı Komitesi (648-1/2018 sayılı Etik Kurul) tarafından onaylanmıştır. BA ve CP saf su içinde çözülmüştür. Kontrol grubu hayvanlarına, 6 gün boyunca $0.5 \mathrm{~mL}$ salin verildi. Sadece $\mathrm{CP}$ verilen grupta, hayvanlara 6 gün boyunca her gün $0.5 \mathrm{~mL}$ salin, deneyin dördüncü gününde CP $(200 \mathrm{mg} / \mathrm{kg})$ uygulanmıştır [11]. BA grubuna ait hayvanlar 6 gün boyunca her gün BA (200 mg / kg) almıştır. BA + $\mathrm{CP}$ grubuna ait hayvanlara, deneyin ilk 3 günü sadece $\mathrm{BA}$ uygulanmış olup deneyin 4 . günü $\mathrm{BA}+\mathrm{SF}$ birlikte uygulanmıştır. Deneyin 5. ve 6. günü sadece BA uygulanmıştır. Deneyin 7. gününde, tüm deney gruplarındaki hayvanlar, kan ve kalp dokularını değerlendirmek üzere anestezi edilmiştir [12].

\subsection{Serum Örneklerinin Hazırlanması ve Biyokimyasal Analiz}

\subsubsection{Kardiyak Enzimlerin Değerlendirilmesi}

Laktat dehidrogenaz (LDH) ve kreatin kinaz-MB'nin (CK-MB) serum aktiviteleri, üreticinin talimatlarına göre, bir otoanalizörde ticari kitler (Sigma-Aldrich) kullanılarak analiz edilmiştir. (HITACHI-917, Wiesbaden, Almanya).

\subsection{2. İskemi-Modifiye Albüminin Ölçümü (IMA)}

Serumda IMA ölçümü Bar-Or ve ark., [13] tanımladığı yönteme göre spektrofotometrik olarak yapılmıştır.

\subsection{Histolojik analiz}


Kalp dokusu, \% 10 formaldehit çözeltisi ile tespit edilmiştir. Rutin histolojik doku takibinden sonra alınan $5.0 \mu \mathrm{m}$ kalınlığında kesitler Hematoksilen-Eozin (H\&E) ile boyanarak histopatolojik değerlendirmeler için preparat haline getirilmiştir.

\section{4. İstatistiksel analiz}

Veri analizleri SPSS 20.0 ve Sigma Stat yazılım paketleri ile yapılmıştır. Bağımsız ölçümler ve normal dağılımlı sürekli veriler One Way Anova ile analiz edilmiştir. Anormal dağılım gösteren skorlara Kruskal-Wallis testi uygulanmıştır. Deney grupları arasında gözlenen farklar $p<0,001$ ise anlamlı kabul edilmiştir.

\section{Bulgular ve Tartışma}

$\mathrm{Bu}$ çalışma, SF nedenli kalp hasar gelişiminin antioksidan özelliği bilinen BA tarafindan önlenip önleyemediğini araştırmıştır. Histopatolojik bulgular Şekil 1'de gösterilmiştir. Şekil 1 incelendiğinde, kontrol ve sadece $200 \mathrm{mg} / \mathrm{kg}$ BA verilen gruplarda tek çekirdekli, şekil olarak oval yapıya sahip normal kalp dokusu görülmüştür. Sadece CP verilen hayvanlarda, kardiyak kas hücrelerinde eozinofilik boyanma, hücresel ödem, yoğun kromatine bağlı olarak çekirdeğin küçülmesi, koyu boyanma ve çekirdek sınırlarında düzensizlik gözlenmiştir. Ayrıca, küçük çaplı kanamalar ve ödem bölgeleri nedeniyle kardiyomiyositlerin ayrılması tespit edilmiştir. CP uygulamasından önce BA ile ön koruma yapılan deney grubuna ait kalp dokusu kesitleri incelendiğinde kontrole oldukça benzer olduğu saptanmıştır. Çalışmada elde ettiğimiz histopatolojik bulgulara benzer olarak, Çetik ve ark., [1] çalışmalarında $\mathrm{CP}(150 \mathrm{mg} / \mathrm{kg})$ verilen deney gruplarına ait kalp dokusunda, hücre stoplazmalarında boyanma özelliklerinde değişmeler, çekirdeklerinde daha koyu renk ve büzülmeler, kas hücrelerinin arasında kanamalar, küçük iltihabi hücre odakları, kas liflerinde birbirinden ayrılmalar olduğunu göstermişlerdir. Bir başka çalışmada ise $200 \mathrm{mg} / \mathrm{kg}$ CP verilen sıçanlarda, miyokardta hemorajik odaklar, miyokardiyal liflerde bozulma ve hiyalinleşme olduğu gösterilmiştir [14]. Çalışmamızın histolojik bulguları araştırıcılar tarafından ileri sürülen bulgular ile paralellik göstermektedir.

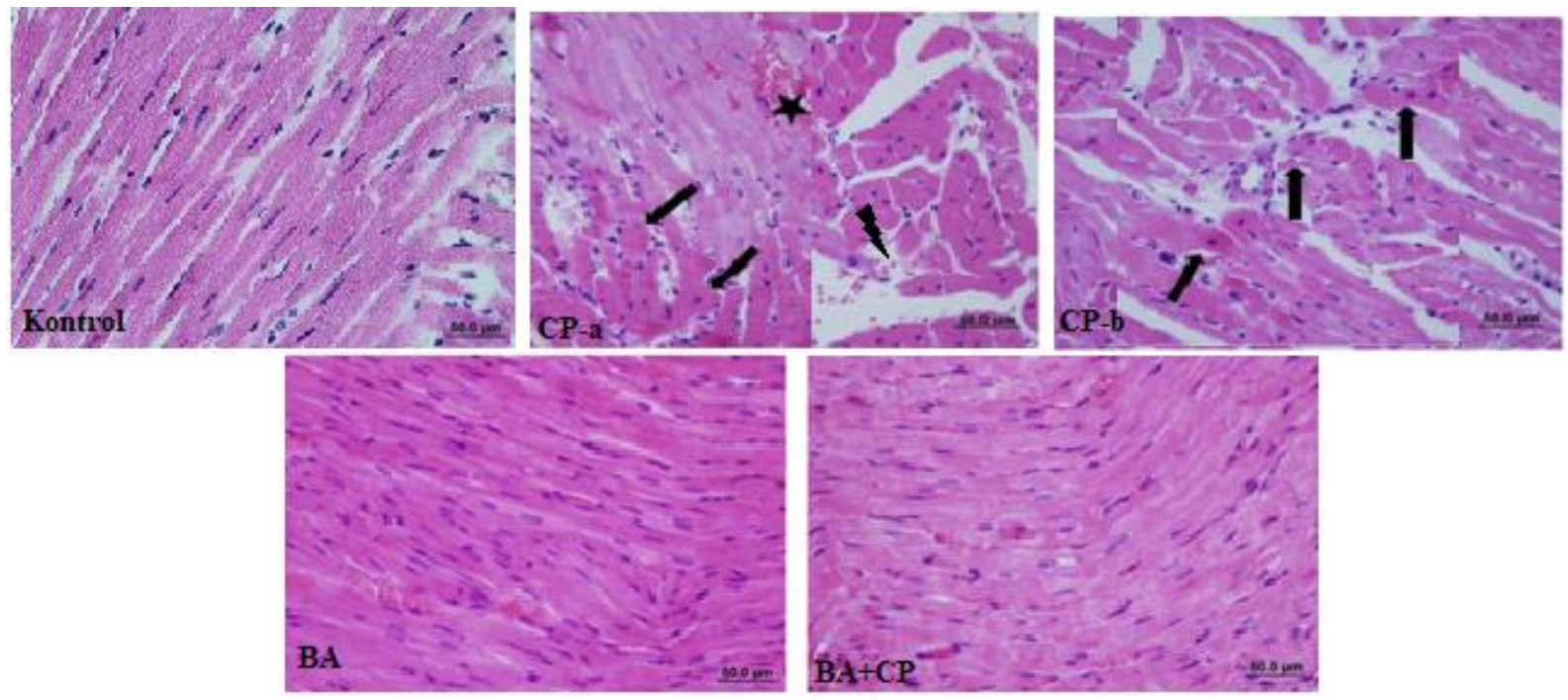

Şekil 1. Normal histolojisi olan kalp dokularında H+E boyama (Kontrol ve BA grubu), ödem, koyu ve küçülmüş çekirdekler (oklar) nedeniyle birbirinden ayrılmış koyu eozinofilik sitoplazmalı, hemoraji (asteriks), hücresel ödem (şimşek) ve anormal bazofilik lekeli kardiyak kas hücrelerinin küçük bir odak noktası; (CP-a ve CP-b) ve kalp dokusunun normal histolojik yapısına sahip görüntüsü (BA+ $\mathrm{CP})$.

Diğer taraftan biyokimyasal değerlendirmemizde, kalp kası hasarının spesifik göstergeleri olan serum CK-MB, LDH ve IMA düzeylerinin, $200 \mathrm{mg} / \mathrm{kg} \mathrm{CP}$ verilen deney grubunda önemli oranda arttı̆ 1 belirlenmiştir (Şekil 2,3 ve 4). Bu durum kalp dokusunun CP varlığında hasarlandığını göstermektedir. $\mathrm{CP}$ ile birlikte verilen $200 \mathrm{mg} / \mathrm{kg}$ BA'nın, CK-MB düzeyini kontrol düzeyine yaklaştırarak iyileşme yaptığı saptanmıştır. Bulgularımızla uyumlu olarak, yapılan klinik bir çalışmada, CP kemoterapisinin 
kardiyak hasarın belirleyicisi olan CK-MB'yi arttırdığı bildirilmiştir. Yousif [4], sıçanlarda yaptığı deneysel bir çalışmada, $200 \mathrm{mg} / \mathrm{kg}$ CP'nin kalp dokusunda oksidatif stres ile birlikte CK-MB ve LDH seviyelerinde artışa ve miyokardiyal disfonksiyona neden olduğunu rapor etmiştir. Yine bir çalışmada, Mythili ve ark., [15] sıçanlarda CP'nin kalp dokusunda serum LDH ve CK-MB düzeyini arttırdığını, akut kalp yetmezliği ve histopatolojik lezyonların görüldüğünü vurgulamışlardır. Buna karşılık çalışmamızda $\mathrm{BA}+\mathrm{CP}$ verilen grupta $\mathrm{CK}-\mathrm{MB}, \mathrm{LDH}$ ve IMA düzeyleri sadece $\mathrm{CP}$ verilen gruba göre önemli oranda azalma göstermiştir $(p<0.05)$.

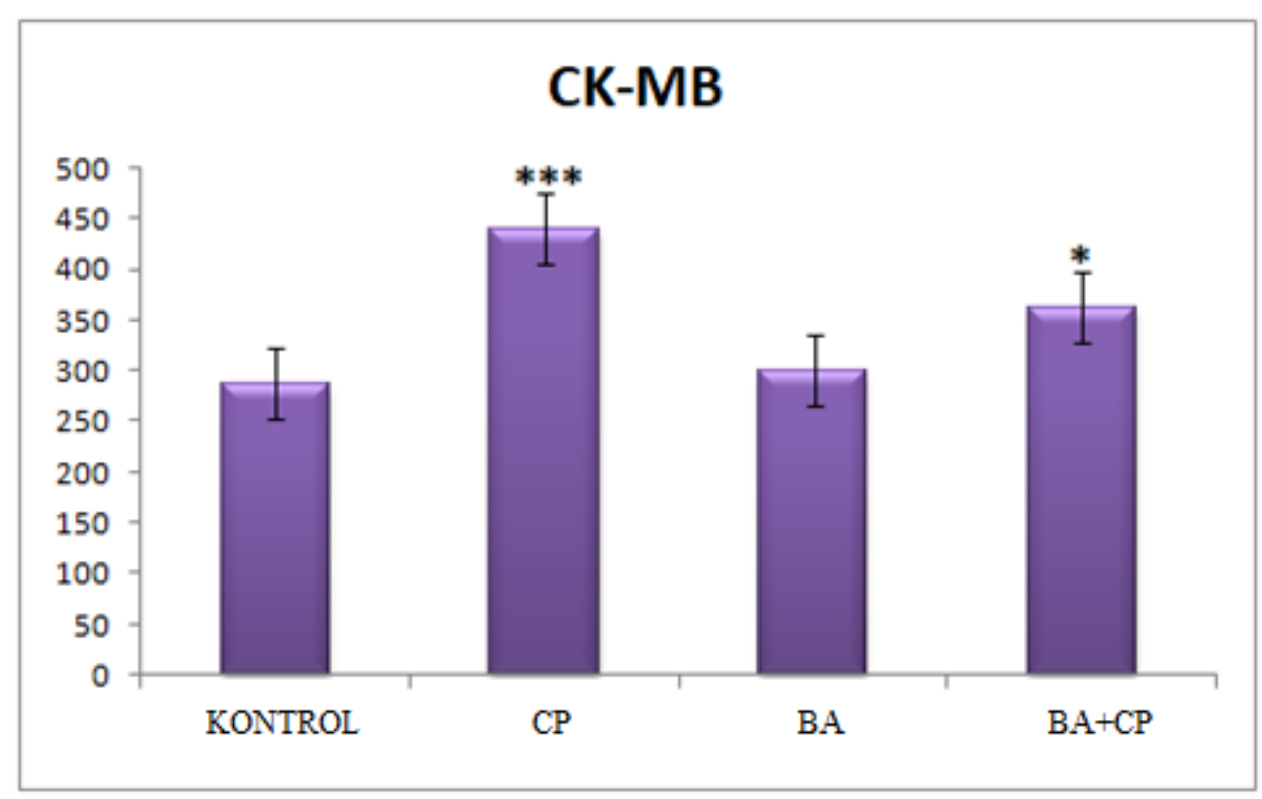

Şekil 2. Deney gruplarının CK-MB (U/L) değerleri bakımından kontrol grubuna göre ortalama değerlerinin istatistiksel karşılaştırması. ${ }^{* * *} ; p<0.001$ ileri derecede anlamlı fark, *:p<0.05 anlamlı fark 


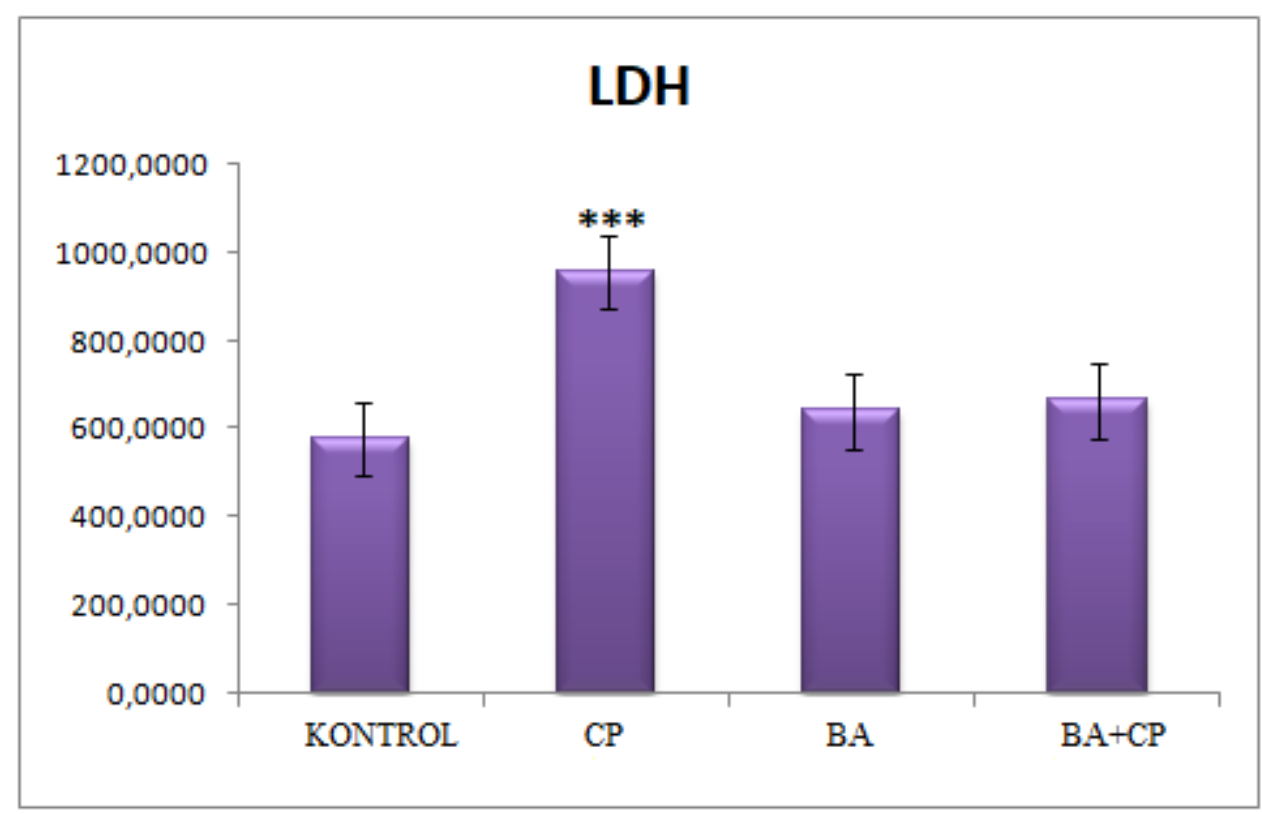

Şekil 3. Deney gruplarının LDH (U/L) değerleri bakımından kontrol grubuna göre ortalama değerlerinin istatistiksel karşılaştırması. ${ }^{* * *} ; p<0.001$ ileri derecede anlamlı fark, $*: p<0.05$ anlamlı fark

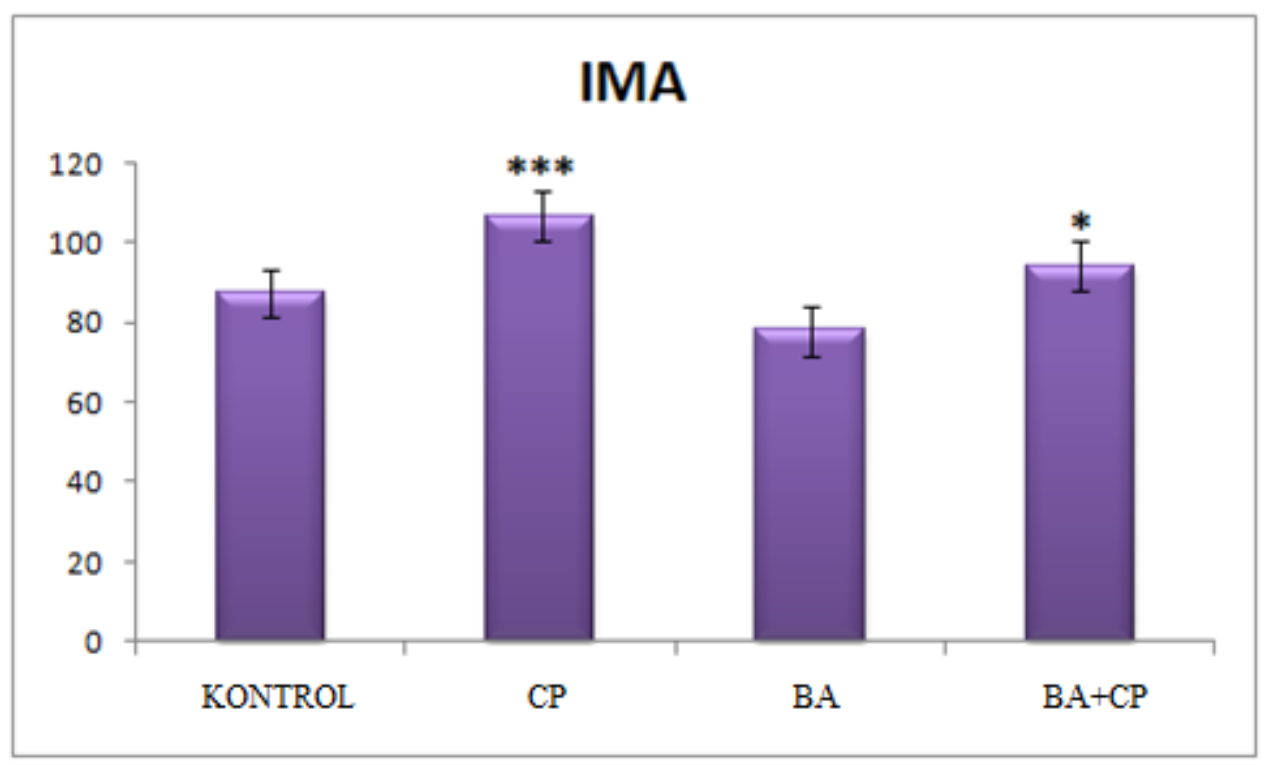

Şekil 4. Deney gruplarının IMA (ABSU: absorbans ünitesi) değerleri bakımından kontrol grubuna göre ortalama değerlerinin istatistiksel karşılaştırması. ${ }^{* * *} ; p<0.001$ ileri derecede anlamlı fark, $*: p<0.05$ anlamlı fark

\section{Sonuçlar ve Öneriler}

Çalışmamızda gözlenen doku hasarı, CP metabolitlerinin neden olduğu membran hasarı ile ilgili olduğunu göstermektedir. Nitekim, bu patolojik değişiklikler hasar markırlarının seviyelerinde meydana gelen değişimler ile de uyumludur. CP ile birlikte uyguladığımız BA'nın bu doku hasarı ve nekroz gibi anormal patolojik bulguları azalttığı ve kalp dokusunu oksidatif hasara karşı koruduğunu göstermektedir. Çalışmamızın bulguları CP nedenli doku hasarı, antioksidan ve membranı stabilize edici 
özellik gösteren BA ile korunabileceğini göstermektedir. Ancak bu konuda özellikle kullanılan doz yönünden daha detaylı çalışmalar yapılmalı ve yeni in-vivo yöntemler de denenmelidir.

\section{Kaynaklar}

1. Cetik S. 2014. Siçanlarda Siklofosfamid Nedenli Kardiyotoksisitede Oksidatif Stres ve Kalp Hasarına Karşı Karvakrol'ün Koruyucu Etkisi. Eskişehir Osmangazi Üniversitesi, Fen Bilimleri Enstitüsü, Doktora Tezi, 3s, Eskişehir.

2. Nagi M., Al-Shabanah O., Hafez M., Sayed-Ahmed M. 2010. Thymoquinone Supplementation Attenuates Cyclophosphamide-induced Cardio toxicity in Rats. Journal of Biochemical and Molecular Toxicology, 25 (3): 135-42.

3. Kawabata T.T., Chapman M.Y., Kim D.H., Stevens W.D., Holsapple M.P. 1990. Mechanism of in vitro Immunosuppression by Hepatocyte Generated Cyclophosphamide Metabolites and 4Hydroxicyclophosphamide, Biochemical Pharmacology, 40 (5): 927-935.

4. Yousif A. 2010. Attenuates Cyclophosphamide-induced Oxidative Apoptosis, p53 and Bax Signal Expression in Rat Cardiac Tissues. Oxidative Medicine and Cellular Longevity, 3 (5): 308-316.

5. Janero D.R., Hreniuk, D., Sharif, H.M. 1991. Hydrogen peroxide-induced oxidative stress to the mammalian heart-muscle cell (cardiomyocyte): Lethal peroxidative membrane injury. Journal of Cellular Physiology, 149 (3): 347-364.

6. Shanholtz C.2001. Acute life-threatening toxicity of cancer treatment. Critical Care Clinics, 17 (3): 483-502.

7. Ludeman S.M. 1999. The chemistry of the metabolites of cyclophosphamide. Current Pharmaceutical Design, 5 (8): 627-643.

8. Henderson K., Stella S.L., Kobylewski S., Eckhert C.D. 2009. Receptor activated $\mathrm{Ca}^{2+}{ }^{2+}$ release is inhibited by boric acid in prostate cancer cells. PLoS One, 4 (6): e6009.

9. Ustundag A., Behm C., Follmann W., Duydu Y., Degen G.H. 2014. Protective effect of boric acid on lead- and cadmium-induced genotoxicity in V79 cells. Archives of Toxicology, 88 (6): 12811289.

10. Sogut I., Oglakci A., Kartkaya K., Ol K.K., Sogut M.S., Kanbak G., Inal M.E. 2015. Effect of boric acid on oxidative stress in rats with fetal alcohol syndrome. Experimental and Therapeutic Medicine, 9 (3): 1023-1027.

11. Goudarzia M., Khodayara MJ., Tabatabaeib S.M.T.H., Ghaznavic H.F.I., Mehrzadi S. 2017. Pretreatment with melatonin protects against cyclophosphamide-induced oxidative stress and renal damage in mice. Fundamental \& Clinical Pharmacology, 625-635.

12. Cengiz M. 2018. Hematoprotective effect of boron on cyclophosphamide toxicity in rats. Cellular and Molecular Biology, 64 (5): 62-65.

13. Bar-Or D., Lau E., Winkler J.V. 2000. A novel assay for cobalt-albumin binding and its potential as a marker for myocardial ischemia - a preliminary report. Journal of Emergency Medicine, 19: 311-315.

14. Tarek M.K., Motawi Nermin A.H., Sadik A.R. 2010. Cytoprotective effects of DL-alpha-lipoic acid or squalene on cyclophosphamide-induced oxidative injury: An experimental study on rat myocardium, Testicles and urinary bladder. Food and Chemical Toxicology, 48 (8-9): 2326-2336.

15. Mythili Y., Sudharsan P,T, Selvakumar E,, Varalakshmi P. 2004. Protective effect of DL- $\alpha$-lipoic acid on cyclophosphamide induced oxidative cardiac injury. Chemico-Biological Interactions, 151 (1): 13-19. 